NBER WORKING PAPER SERIES

\title{
BANK SUPERVISION AND CORRUPTION IN LENDING
}

\author{
Thorsten Beck
}

Asli Demirgüç-Kunt

Ross Levin

Working Paper 11498

http://www.nber.org/papers/w11498

\author{
NATIONAL BUREAU OF ECONOMIC RESEARCH \\ 1050 Massachusetts Avenue \\ Cambridge, MA 02138 \\ June 2005
}

Beck and Demirgüç-Kunt: World Bank; Levine: Carlson School of Management at the University of Minnesota and the NBER. This paper's findings, interpretations, and conclusions are entirely those of the authors and do not necessarily represent the views of the World Bank, its Executive Directors, or the countries they represent. We thank J. Boyd, G. Caprio, G. Clarke, C. Plosser, C. Schenone, an anonymous referee, and seminar participants at the Banco Central de Chile, Bank of England, Brown University, European Central Bank, London Business School, London School of Economics, NYU's Stern School of Business, Oxford University's Said Business School, University of Berne, University of PennsylvaniaWharton, University of Tübingen, and the University of Minnesota for helpful suggestions. An earlier version of this paper circulated under the title, Bank Supervision and Corporate Finance. The views expressed herein are those of the author(s) and do not necessarily reflect the views of the National Bureau of Economic Research.

(C2005 by Thorsten Beck, Asli Demirgüç-Kunt and Ross Levine. All rights reserved. Short sections of text, not to exceed two paragraphs, may be quoted without explicit permission provided that full credit, including (C) notice, is given to the source. 
Bank Supervision and Corruption in Lending

Thorsten Beck, Asli Demirgüç-Kunt and Ross Levine

NBER Working Paper No. 11498

July 2005

JEL No. G3, G28, L51, O16

\section{$\underline{\text { ABSTRACT }}$}

Which commercial bank supervisory policies ease - or intensify - the degree to which bank corruption is an obstacle to firms raising external finance? Based on new data from more than 2,500 firms across 37 countries, this paper provides the first empirical assessment of the impact of different bank supervisory policies on firms' financing obstacles. We find that the traditional approach to bank supervision, which involves empowering official supervisory agencies to directly monitor, discipline, and influence banks, does not improve the integrity of bank lending. Rather, we find that a supervisory strategy that focuses on empowering private monitoring of banks by forcing banks to disclose accurate information to the private sector tends to lower the degree to which corruption of bank officials is an obstacle to firms raising external finance. In extensions, we find that regulations that empower private monitoring exert a particularly beneficial effect on the integrity of bank lending in countries with sound legal institutions.

Thorsten Beck

The World Bank

MSN MC 3-300

1818 H Street NW

Washington, DC 20433

tbeck@worldbank.org

Asli Demirgüç-Kunt

Economics Research

World Bank Group

1818 H Street NW

Washington, DC 20433

ademirguckunt@worldbank.org
Ross Levine

Department of Economics

Brown University

64 Waterman Street

Providence, RI 02912

and NBER

rlevine@csom.umn.edu

(From August 1, 2005) 


\section{Introduction}

Banks provide a substantial proportion of external finance to enterprises around the globe. Yet, there have been no previous studies of whether international differences in bank supervision influence the obstacles that corporations face in raising external finance. Furthermore, the Basel Committee, International Monetary Fund and World Bank promote the development of powerful bank supervisory agencies with the authority to monitor and discipline banks. Yet, there exists no cross-country evidence to support these recommendations, nor is there evidence on the general question of which bank supervisory policies facilitate efficient corporate finance.

This paper provides the first assessment of the relationship between bank supervisory policies and the degree to which corruption in lending impedes the ability of firms to raise external finance. Theory provides conflicting predictions about the impact of bank supervisory policies on the extent to which corruption of bank officials impedes the efficient allocation of bank credit. Thus, by examining the integrity of bank lending, we distinguish among different approaches to supervision as well as more general theories of the role of government in the economy.

Indeed, general theories of government regulation provide a natural framework for assessing bank supervision. When information costs, transactions costs, and government policies interfere with the incentives and abilities of private agents to monitor banks, strong official supervision of banks can improve the corporate governance of banks (Stigler, 1971). ${ }^{1}$ This "supervisory power view" holds that private agents frequently lack the incentives and capabilities to monitor powerful banks. From this perspective, a powerful supervisory agency that directly monitors and disciplines

\footnotetext{
${ }^{1}$ Also, see Becker (1968) and Becker and Stigler (1974). Furthermore, some may reject the importance of market failures in banking. In a world with (i) no information or transactions costs, (ii) governments that maximize social welfare, and (iii) well-defined and efficiently enforced property rights, market participants will achieve efficient outcomes (Coase, 1960). If the prerequisites for this laissez-faire - invisible hand - theory hold, government supervision of banks would be at best irrelevant and potentially harmful to social welfare (Stigler, 1975). The empirical evidence below also provides evidence on this laissez-faire view.
} 
banks can enhance the corporate governance of banks, reduce corruption in bank lending, and thereby boost the efficiency with which banks intermediate society's savings. The official supervision theory assumes that governments have both the expertise and the incentives to ameliorate market imperfections and improve the governance of banks.

An alternative to the supervisory power view also draws on core theories of public policy and regulation. The "political/regulatory capture view" argues that politicians and supervisors do not maximize social welfare; they maximize their own private welfare (Hamilton, et al., 1788; Buchanan and Tullock, 1962; Becker, 1983; Shleifer and Vishny, 1998). Thus, if bank supervisory agencies have the power to discipline non-compliant banks, then politicians and supervisors may use this power to induce banks to divert the flow of credit to politically connected firms (Becker and Stigler, 1974; Stigler, 1975; Haber et al., 2003). Under these conditions, banks do not only allocate capital based on risk-return criteria. Rather, when supervisory agencies have the power to influence the distribution of bank loans, then corruption and political ties may shape the allocation of bank credit. This theory suggests that strengthening the power of the supervisory agency may actually reduce the integrity of bank lending with adverse implications on the efficiency of credit allocation. Logical extensions of the political/regulatory capture view imply that powerful supervisory agencies will have less of a tendency to abuse their power for private gain in countries with sound institutions that constrain exploitative behavior by government officials. We test this hypothesis below.

Finally, the "private empowerment view" argues that bank supervisory policies should focus on enhancing the ability and incentives of private agents to overcome information and transaction costs, so that private investors can exert effective governance over banks. The private empowerment view simultaneously recognizes the potential importance of market failures, which motivate government intervention, and political/regulatory failures, which suggest that supervisory 
agencies do not necessarily have incentives to ease market failures. Consequently, the private empowerment view seeks to provide supervisors with the responsibility and authority to induce banks to disclose accurate information to the public, so that private agents can more effectively monitor banks (Hay and Shleifer, 1998). This view also holds that many empowered private bank creditors will be less susceptible to capture by politicians and banks than a single supervisory agency. Furthermore, the private empowerment view stresses that transparent information will help private investors exert effective corporate governance over banks only when sound legal institutions operate in the country. Thus, the private empowerment view holds that corruption of bank officials will be less of a constraint on corporate finance in countries that foster public information disclosure and have well-functioning legal institutions than in countries that rely on powerful official supervisors.

This paper is further motivated by recent trends in corporate finance and public policy debates. First, an enormous theoretical literature examines the role of banks, along with shareholders and other financiers, in easing financing constraints and exerting corporate governance (Shleifer and Vishny, 1997; Morck, Wolfenzon, and Yeung, 2005). Based on some of these models, empirical research examines how laws concerning shareholders influence corporate finance (Beck and Levine, 2005). Yet, there exists no corresponding work that examines how bank supervision influences corporate finance. This paper is an initial attempt to better understand how different supervisory policies influence the obstacles faced by firms in raising external finance.

Second, influential international institutions, such as the Bank for International Settlements, the International Monetary Fund, and the World Bank, are encouraging countries to strengthen bank supervision. Although these recommendations are frequently discussed in the context of avoiding banking crises, crises cannot be the only criterion because policymakers can essentially eliminate 
banking crises through a 100 percent reserve requirement. Thus, an important, if often under-stated, objective of bank supervision is to foster efficient capital allocation; i.e., to finance worthy firms based on market - not corrupt -- criteria. To provide information about which types of bank supervisory strategies work best to promote efficient corporate finance, this paper assesses the impact of different bank supervisory policies on the degree to which bank corruption impedes firms from obtaining external finance.

This paper uses firm-level data on more than 2,500 firms across 37 countries to examine the impact of bank supervision on the obstacles that firms encounter in raising external capital. The firm-level data come from the World Business Environment Survey (WBES), which was conducted in 1999. This dataset includes information on firm characteristics, including the degree to which bank corruption is important to raising capital. These data are based on survey questions in which firms rank the impediments on a scale from one to four, with larger values implying that bank corruption is a greater obstacle.

The bank supervisory data come from Barth, Caprio, and Levine (2004, henceforth BCL). These data include information on official supervisory power, such as the ability to intervene in banks, replace managers, force provisioning, stop dividends and other payments, acquire information, etc. BCL also collect information on the degree to which supervisory authorities facilitate private monitoring of banks by not reducing the incentives of the private sector to monitor banks through deposit insurance and by forcing accurate information disclosure. Specifically, BCL assemble data on whether bank directors and officials face criminal prosecution for failure to disclose information accurately, whether banks must disclose consolidated accounts, whether international accounting firms audit banks, whether there is implicit or explicit deposit insurance, etc. 
Econometrically, we use ordered probit and probit procedures because of the discrete nature of the dependent variable. The dependent variable is the measure of the degree to which corruption of bank officials is an obstacle to firms raising external finance. The main explanatory variables are measures of (1) supervisory power and (2) the degree to which regulations require information disclosure by banks and give private creditors incentives to monitor banks. We also control for a range of firm-specific and country-specific characteristics. We also use instrumental variables to control for potential endogeneity.

The results are inconsistent with the traditional supervisory power view and provide qualified support for the political/regulatory capture view. Specifically, we never find that supervisory power lowers corruption in bank lending. Indeed, even in countries with highly developed institutions (e.g., effective governments and adherence to the rule of law), we do not find that supervisory power improves the integrity of bank lending. Thus, while the BIS, the IMF, and the World Bank are pushing countries to strengthen direct official oversight of banks, the evidence does not support this recommendation. Rather, supervisory power is positively associated with corruption in bank lending. We also find that supervisory power is strongly linked to poor legal system development, low levels of government effectiveness, and high levels of national corruption. Thus, the positive relationship between supervisory power and corruption in bank lending becomes insignificant when we control for these other country characteristics.

The paper also presents evidence that supports the private empowerment view. The data are consistent with the view that policies that force accurate information disclosure and provide incentives to private investors to monitor banks lower the importance of bank corruption in raising external finance. In extensions, we test whether empowering private monitoring only works in particular institutional settings. We find that supervisory practices that force the disclosure of 
accurate, transparent information on banks work best to promote integrity in lending in countries that adhere to the rule of law. Thus, empowering private monitoring of banks has the largest, positive effect in countries with well functioning legal systems.

This paper is related to recent research. BCL conduct a pure cross-country analysis and find that financial development is (1) positively associated with supervisory approaches that force information disclosure and (2) negatively associated with powerful supervisors that directly monitor and discipline banks. In this paper, we use microeconomic data to examine the channels running from bank supervision to corporate finance, rather than examining cross-country connections between bank supervision and banking system size. In a cross-country analysis, La Porta, et al. (2005) find that securities market regulations that induce information disclosure promote stock market development, while securities regulations that rely on official oversight of markets only boost equity market capitalization in countries with efficient government bureaucracies. In this paper, we focus on bank supervision and use firm-level data in assessing the impact of different bank supervisory practices on firms' financing obstacles.

A number of methodological concerns need to be noted. First, individual firms subjectively report financing obstacles. Thus firms facing the same obstacles in two different countries may report different obstacles for reasons that do not depend on actual constraints. Although it is not clear that this would bias the results in any particular direction, we provide evidence on the validity of the survey information below. Second, the supervisory variables might proxy for other country specific factors. Importantly, however, we get the same results when including the official supervisory power and private monitoring variables simultaneously. Thus, supervisory power and private monitoring are not proxying for the same unspecified factor. Also, the results hold even when controlling for many country-specific factors, such as the level of economic development, 
economic growth, macroeconomic stability, overall financial development, differences in political systems, state-ownership of banks, regulatory restrictions on bank activities, the laws governing the rights of creditors and shareholders, and the overall level of corruption in the economy. Third, banking crises may both intensify financing obstacles and boost official supervisory power, producing a spurious relationship between supervisory practices and firm financing obstacles. When we control for crisis, however, the results do not change.

Finally, some may view the paper as an atheoretical exploration of the relationship between bank supervisory practices and the integrity of bank lending. It is true that we do not estimate a single model that explicitly links bank supervisory practices to bank behavior, and then to the corporate financing decisions of firms. We do, however, evaluate broad theories of government regulation along with influential approaches to bank supervision. Also, given the central importance of bank supervisory policies and bank financing around the world, this paper provides initial documentation of the relationships between bank supervision policies and corporate financing constraints that we hope motivate additional theoretical and empirical work.

The remainder of the paper is organized as follows. Section 2 presents the data and the methodology is described in Section 3. Section 4 gives the results and Section 5 concludes.

\section{Data, Summary Statistics, and Links to Theory}

a. Corruption as an obstacle to firms obtaining external finance: Definitions

To examine the relationship between bank supervisory strategies and corporate financing obstacles, we use data from two main sources: the World Business Environment Survey (WBES) for firm-level data and BCL (2004) for country-level data on bank supervision. 
From the WBES, we use information on over 2,500 firms across 37 non-transition economies. While the WBES comprises 80 countries and the BCL database includes data on 107 countries, the limited overlap reduces our sample. The WBES surveyed firms of all sizes; small firms (between 5 and 50 employees) represent $40 \%$ of the sample, medium-sized (between 51 and 500 employees) firms are $40 \%$ of the sample, and the remaining $20 \%$ are large firms (more than 500 employees). The survey comprises mostly firms of the manufacturing, construction and services sectors. We also have information on whether these are government-owned, foreign-owned, or privately-owned firms. The data indicate whether the firm is an exporter and provide information on sales, growth, financing patterns, and the number of competitors.

Bank Corruption equals the response to the question: "Is the corruption of bank officials an obstacle for the operation and growth of your business?" Answers vary between 1 (no obstacle), 2 (a minor obstacle), 3 (a moderate obstacle), or 4 (a major obstacle)?” Thus, bigger numbers imply the corruption of bank officials is a bigger obstacle to obtaining financing. Overall, $7.7 \%$ of the firms in our sample report bank corruption as a major obstacle, $7.8 \%$ rate bank corruption as a moderate obstacle, $19.5 \%$ respond that corruption is a minor obstacle, while $65 \%$ report that the corruption of bank officials is not an obstacle to firm growth. Given this distribution of responses, we sometimes divided the responses into those with a value of one ( $65 \%$ of the responses) and all others. This allows us to use a comparatively balanced distribution of responses, reduce the possible influence of outliers, and use instrumental variable procedures that are available for probit analyses but not ordered probit regressions. The perceived degree to which the corruption of bank officials is an obstacle to efficient corporate finance not only varies across firms within countries, but also across countries. ${ }^{2}$ For instance, the average firm in Thailand reports that the corruption of bank

\footnotetext{
2 The overall standard deviation of the bank corruption variable is 0.93 , while the between country standard deviation is 0.49 , and the within country standard deviation is 0.82 .
} 
officials is a substantial obstacle to obtaining external finance (3.14), while the average firm in Canada or the United Kingdom reports a very high degree of integrity in bank lending (1.03).

b. Obstacles to firms obtaining external finance: Justification

We use a unique database to investigate the impact of bank supervision on the integrity of bank lending. The WBES survey provides information on the degree to which corruption in lending represents an obstacle to firms. Thus, unlike other general measures of firm financing obstacles (Fazzari, Hubbard, and Petersen, 1988; and Demirguc-Kunt and Maksimovic, 1998), the WBES survey provides direct information from firms about specific perceived obstacles and therefore does not infer the existence of general financing constraints from other information. Furthermore, the WBES database has excellent coverage of small and medium size firms (as well as large firms), while other cross-country studies of corporate finance focus almost exclusively on large, listed corporations. Moreover, the WBES has very broad country coverage that is important for linking the firm-level data with the bank supervision data. Finally, we stress that these survey data are conducted at the firm-level. While we examine the relationship between firm-level responses and national supervisory policies, it is inappropriate to aggregate the firm-level survey responses and conduct pure cross-country comparisons because the composition of firms differs markedly across countries. To draw appropriate inferences about the relationship between bank supervisory practices and corruption in lending from this database, one needs to control for firm-specific traits.

As noted in the Introduction, there are good reasons for believing that these self-reported data are not biasing the results in favor of this paper's findings. First, if a firm facing the same obstacles will respond to questions differently in different institutional and cultural environments, then, to the extent that this represents pure measurement error, it would bias the results against finding a significant relationship between bank supervision and firm financing obstacles. Second, 
we obtain the same results when controlling for many country-specific traits. Third, additional work suggests that the survey data are closely associated with other measurable outcomes. Hellman et al. (2000) show that in a sub-sample of 20 countries there is a close connection between responses and measurable outcomes, and they find no systematic bias in the survey responses. Also, reported firm financing obstacles are highly, negatively correlated with firm growth (Beck, Demirguc-Kunt, and Maksimovic, 2005). Furthermore, we examined the connection between reported firm financing obstacles and Wurgler's (2000) measure of the efficiency of investment flows. ${ }^{3}$ We find the reported financing obstacles are negatively and significantly correlated with this efficiency of investment indicator. Finally, we studied the link between survey responses regarding firm financing obstacles and industrial expansion. Based on Rajan and Zingales (1998), we examine whether industries that are naturally heavy users of external finance grow faster in economies where firms face lower reported financing obstacles. We find that externally dependent industries grow faster in countries where firms report the corruption of bank officials is less of an obstacle to firm growth. Thus, firms' responses to the survey on financing obstacles are capturing more than idiosyncratic differences in how firms rank obstacles; the survey data are associated with measurable outcomes.

As an additional robustness check on the usefulness of firm responses to the question regarding the degree to which corruption of bank officials is an obstacle, we re-do all of the analyses controlling for each firm's response to the following question: "How problematic is financing for the operation and growth or your business?” If a particular firm is particularly pessimistic or is simply blaming other factors on its performance, this should be reflected in both its response to this general financing obstacle question as well as is its response to the more specific

\footnotetext{
${ }^{3}$ This is an investment elasticity that gauges the extent to which a country increases investment in growing industries and decreases investment in declining ones.
} 
question on the corruption of bank officials. By incorporating this additional variable in the regressions, we lower the likelihood that idiosyncratic firm responses are biasing the results. Thus, if we obtain the same results even when controlling for each firm's response to this general financing obstacle question, this strengthens the interpretation of an independent relationship between the bank supervision indicators and the degree to which the corruption of bank officials is an obstacle to firms obtaining external finance.

\section{c. Firm-specific traits}

In our analysis of bank supervision and corporate finance, we control for several firm attributes such as ownership. Government takes on the value one if the government owns any percentage of the firm, and Foreign takes on the value one if foreign entities own any fraction of the firm. ${ }^{4}$ Our sample includes $6 \%$ government owned firms and $25 \%$ foreign firms.

We also control for each firm's business, competitive environment, and size. The regressions include dummy variables for whether the firm is an exporting firm (Exporter), whether it is a manufacturing firm (Manufacturing) or a service sector firm (Services). The analyses also include the log of the number of competitors that each firm faces (Number of Competitors). In sum, $39 \%$ of the firms in our sample are in manufacturing and $46 \%$ in service, and on average they face 2.1 competitors. Finally, we include the log of sales in USD as indicator of size (Sales).

The correlation analysis in Table I Panel B indicates that non-exporting firms, domestically owned firms, smaller firms (as measured by sales), and firms with more competitors suffer more from bank corruption.

\footnotetext{
${ }^{4}$ While these simple zero-one indicators of ownership may not capture the varying degrees of influence that arise from different levels of government or foreign ownership, information on the percentage of ownership is available for less than 10 percent of the sample. However, among the firms for which we have data on the percentage of foreign and government ownership, more than two thirds of firms with foreign ownership are majority foreign owned and more than $60 \%$ of firms with government ownership are majority state-owned.
} 


\section{d. Bank supervisory policies}

We use two indicators of supervisory practices to test the empirical validity of the competing hypotheses outlined in the Introduction. These indicators and other key country characteristics are listed in Appendix Table I.

Supervisory Power is constructed from 14 dummy variables that indicate whether bank supervisors can take specific actions against bank management, bank owners, and bank auditors both in normal times and times of distress. This includes information on whether the supervisory agency can force a bank to change its internal organizational structure, suspend dividends, stop bonuses, halt management fees, force banks to constitute provisions against actual or potential losses as determined by the supervisory agency, supersede the legal rights of shareholders, remove and replace managers and directors, obtain information from external auditors, and take legal action against auditors for negligence. ${ }^{5}$ Supervisory agencies can use these powers to improve the governance of banks as emphasized by the supervisory power view. The supervisory authority can also use these powers to induce banks to funnel credit to favored ends as emphasized by the political/regulatory capture view. The exact definition of Supervisory Power is provided in the data appendix. We use the first principal component indicator of these variables, which varies between 3.05 (Singapore) and 1.14 (U.S.) with a mean of -0.11 , and higher values indicating wider authority for bank supervisors. ${ }^{6}$

The Supervisory Power variable relates to the theoretical debate discussed in the Introduction. The supervisory power view predicts that strengthening official oversight of banks

\footnotetext{
${ }^{5}$ Note, we obtain the same results when using a proxy for supervisory power that only includes information on the power of the supervisory agency over the bank and excludes the power of the supervisory agency over external auditors. We prefer the broader measure because the supervisory power view holds that only a supervisory agency that has both the information and the power can improve the corporate governance of banks.

${ }^{6}$ The mean is not exactly equal to zero because we use the raw data from Barth et al. (2004) on the supervisory indicators. These data are available for more countries than the corresponding data on firm obstacles.
} 
(increasing Supervisory Power) will improve the governance of banks and increase the likelihood that bank allocate capital based on sound risk-return tradeoffs, so that Supervisory Power will be negatively associated with Bank Corruption. ${ }^{7}$ In direct contrast, the political/regulatory capture view predicts that Supervisory Power will be positively associated with Bank Corruption. In particular, the political/regulatory capture view holds that increases in the power of the official supervisory agency to discipline and replace bank directors and managers gives the agency grater influence over the allocation of bank credit. If official supervisors have the incentives and ability to use this power to promote private interests rather than the public good, then credit allocation will potentially reflect political ties, bribes and more subtle emoluments such as family connections and future employment opportunities. In this environment, firms will perceive that credit is not simply allocated based on risk-return criteria and will therefore be more likely to respond that corruption in bank lending hurts the operation and growth of their businesses. Below, we also discuss and test more subtle versions of the political/regulatory capture view which stress that in countries with sound legal and political institutions, supervisory power will not be abused. From this perspective, the impact of supervisory power on the integrity of bank lending depends on institutional development.

Private Monitoring is designed to measure the degree to which bank supervision forces banks to disclose accurate information to the public and induces private sector monitoring of banks. Private Monitoring is constructed from nine dummy variables that measure whether bank directors and officials are legally liable for the accuracy of information disclosed to the public, whether banks must publish consolidated accounts, whether banks must be rated and audited, whether banks must

\footnotetext{
${ }^{7}$ See Polinsky and Shavell's (2000) review of the theory of public enforcement and the discussion in Coase (1988). Also, Spiller and Ferejohn (1992) note that lawmakers do not have sufficient information to anticipate all possible circumstances. Thus, there may be efficiency gains to delegating power to a supervisory agency that has the expertise and resources to set and change the specific rules as events evolve.
} 
be audited by certified international auditors, whether subordinated debt is allowable (which may create a class of private monitors), and whether there is both no explicit deposit insurance and no actual insurance was paid the last time a bank failed (as a measure of the existence of an implicit deposit insurance regime). The Private Monitoring Index is constructed as a principal component indicator, with higher values indicating more tools and incentives for private bank creditors to monitor banks, ranging from -1.56 (Ghana) to 1.46 (United Kingdom).

In terms of theory, the private empowerment view holds that supervisory policies that force accurate information disclosure and give private creditors appropriate incentives can ameliorate market failures without increasing the likelihood of political/regulatory capture. According to this view, forcing banks to provide transparent comparable information to the public enhances private sector oversight of banks and reduces the degree to which bank allocate credit on non-market terms. Thus, the private empowerment view holds that Private Monitoring will be negatively associated with Bank Corruption. As we develop further below, this private empowerment view presumes that the private agents have a sufficiently well-functioning legal system at their disposal so that they can exert effective corporate governance over banks when supervisory practices force the disclosure of accurate information. Thus, more sophisticated versions of the private monitoring view predict that enhancing information transparency will only improve the integrity of bank lending in countries with sufficiently well-functioning legal systems. We test this below. 


\section{e. Country-level control variables}

To assess the robustness of the relation between bank supervision and firms' access to external financing, we include other country-level variables. We include the growth rate of GDP per capita (Growth) since firms in faster growing countries may face lower obstacles. We use the inflation rate (Inflation) to proxy for monetary instability, conjecturing that firms in more stable environments face fewer obstacles (Boyd, Levine, and Smith, 2001).

We also include the level of overall banking sector development (Priv), which equals credit by banks to the private sector as a share of GDP, since we want to assess the impact of supervision on corporate finance independent of overall bank development. Bank development is positively associated with economic growth (King and Levine, 1993; Levine and Zervos, 1998; Levine, Loayza, and Beck, 2000). Demirguc-Kunt and Maksimovic (1998) argue that financial development influences growth by easing the external financing constraints faced by firms. Thus, we examine the independent impact of bank supervision on the financing obstacles faced by firms after controlling for overall financial development and conditions in the macroeconomic economy. As shown in Table I, Panel C, firms in poorer countries with higher inflation, lower bank development, and less information disclosure report higher financing obstacles (Table II Panel C).

In our sensitivity analyses, we include a variety of country controls. Specifically, we control for (i) GDP per capita, which measures the overall level of economic development, (ii) State Ownership, which equals the share of a country's bank assets that are held by banks that are more than 50 percent government owned; (iii) Banking Crisis, which equals one if the country has experienced a systemic banking crisis during the 1990s and zero otherwise; (iv) Shareholder Rights, which is a measure of the legal rights of minority shareholders vis-à-vis management and large shareholders; (v) Corruption, which is a measure of the absence of corruption of government 
officials, so that larger values signify less corruption, (vi) Rule of Law, which measures legal system efficiency, and (vii) Government Effectiveness, which is a measure of bureaucratic quality. The Appendix defines these variables and we discuss them further when we present the sensitivity analyses.

\section{The Empirical Model}

To examine bank supervision and corporate finance, we assume that the enterprise's underlying response can be described by the following equation:

Bank Corruption $_{\mathrm{j}, \mathrm{k}}=\alpha+\beta_{1}$ Government $_{\mathrm{j}, \mathrm{k}}+\beta_{2}$ Foreign $_{\mathrm{j}, \mathrm{k}}+\beta_{3}$ Exporter $_{\mathrm{j}, \mathrm{k}}+\beta_{4}$ No. of Competitors $_{\mathrm{j}, \mathrm{k}}$ $+\beta_{5}$ Manufacturing $_{\mathrm{j}, \mathrm{k}}+\beta_{6}$ Services $_{\mathrm{j}, \mathrm{k}}+\beta_{7}$ Size $_{\mathrm{j}, \mathrm{k}}+\beta_{8}$ Inflation $_{\mathrm{k}}+\beta_{9}$ Growth $_{\mathrm{k}}+\beta_{10}$ Priv $_{\mathrm{k}}+\beta_{11}$ Supervision $_{\mathrm{k}}+\varepsilon_{\mathrm{j}, \mathrm{k}}$.

The $\mathrm{j}$ and $\mathrm{k}$ subscripts indicate firm and country respectively. The variable Supervision in equation (1) represents one - or more - of the various supervision variables discussed earlier. These supervisory indicators change across the different specifications as we discuss below.

Unlike the underlying variable, the observed variable Bank Corruption is a polychotomous dependent variable with a natural order. Specifically, the enterprise classifies the degree to which bank corruption is an obstacle with $\mathrm{k}=1,2,3$, or 4 if the underlying variable is between $\alpha_{\mathrm{k}-1}$ and $\alpha_{k+1}$, with the $\alpha$-vector being estimated together with the coefficient vector $\beta$. We therefore use the ordered probit model to estimate equation (1). We use standard maximum likelihood estimation with heteroskedasticity-robust standard errors. Furthermore, we allow for clustering within countries to allow for possible correlation of errors. Specifically, we do not require that the error terms are independent across firms within the same country; rather, we require that error terms are independent across countries. The results hold when we do not allow for clustering and simply run a standard ordered probit under the assumption of independent observations. The coefficients from 
the estimation (with or without clustering), however, cannot be interpreted as marginal effects of a one-unit increase in the independent variable on the dependent variable, given the non-linear structure of the model. Rather, the marginal effect is calculated as $\phi(\beta$ ' $x) \beta$, where $\phi$ is the standard normal density at $\beta^{\prime} \mathrm{x}$. We also include the Pseudo $\mathrm{R}^{2}$, a measure of goodness of fit, which is computed as one minus the ratio of the log likelihood of the full model to the log likelihood of the "constant-only" model.

\section{Results}

\section{A. Findings}

Table II presents regression results where the dependent variable is Bank Corruption. In every regression we control for the array of firm-specific traits discussed above as well as the macroeconomic controls: Inflation, Growth, and Priv. To this set of control variables, the first regression adds Supervisory Power, and the second adds Private Monitoring. The third regression adds Supervisory Power and Private Monitoring simultaneously.

The final regression in Table II includes all the firm-specific variables, the macroeconomic controls, the two supervisory indicators and also includes as an additional control variable, General Financing Obstacle, which equals each firm's response to the question: "How problematic is financing for the operation and growth of your business?" Controlling for this general question about firm financing obstacles reduces the likelihood that reporting biases or interpretational differences across firms drive the results on the relationship between bank supervisory approaches and the degree to which bank corruption impedes efficient corporate finance. While including this firm-specific response may induce simultaneity bias by adding a regressor that is a priori likely to be highly correlated and co-determined with the dependent variable, adding this control variable 
should clearly bias the results against finding any relationship between bank supervisory policies at the country level and firms' responses regarding bank corruption. Thus, we include it as a robustness test.

The results in Table II are inconsistent with the supervisory power view. The supervisory power view emphasizes that information costs, transaction costs, and other government policies interfere with the ability of private agents to monitor banks. Thus, powerful supervisory agencies can improve the governance of banks and thereby minimize the degree to which bank corruption represents an obstacle to firms raising external finance. Contrary to the predictions of the supervisory power view, however, Supervisory Power never enters negatively in any of the regressions. This suggests that powerful supervisors, i.e., supervisors that have the power to oversee and discipline banks do not lower the importance of corruption. Indeed, rather than entering negatively, Supervisory Power enters positively and significantly in all of the regressions.

The Table II regression results support the political/regulatory capture view. The political/regulatory capture view holds that politicians or banks will capture official supervisors and thus increase the importance of corruption in obtaining bank credit and thereby intensify the financing obstacles faced by firms. In fact, Supervisory Power enters significantly and positively in all of the Table II regressions, which confirms the core predictions of the political/regulatory capture view. These results are robust. Even when controlling for the degree to which policies emphasize Private Monitoring, Supervisory Power enters positively and significantly. Furthermore, when we include information on each firm's view of the degree to which General Financing Obstacles hinder its growth, the results still yield a significant, positive coefficient on Supervisory Power. 
The Table II results also support the private empowerment view. The corruption of bank officials is less of a constraint on the operation and growth of firms in countries where the supervisory agency forces banks to disclose information to the private sector. This is not an argument for laissez-faire. Rather, the Private Monitoring variable is a conglomerate indicator of the degree to which supervisory policies force banks to disclose accurate information to the public and the degree to which deposit insurance reduces the incentives of private agents to monitor banks. Thus, the results suggest that supervisory authorities that actively promote accurate information dissemination and do not distort the incentives of depositors to exert corporate governance over banks tend to promote the efficient corporate finance. In sum, the Table II results are strongly supportive of the private empowerment view: corrupt bank officials are less of a barrier to raising capital in countries where supervisory policies force banks to disclose accurate information and give private creditors the appropriate incentives.

The effect of supervisory practices on firms' financing obstacles is not only statistically significant, but also economically relevant, and the econometric model fits the data well. We compute the change in the probability that a firm rates the corruption of bank official as a major obstacle (i.e., the probability that a firm rates bank corruption as a four) when changing bank supervisory policies based on the coefficients in the last regression of Table II (column 4). For example, the estimates imply that if a country moves from the $25^{\text {th }}$ percentile of Supervisory Power to the $75^{\text {th }}$ percentile, the probability that a firm rates bank corruption as a major obstacle increases from $6.8 \%$ to $9.2 \%$. This 2.4 percentage point increase is quite large given that less than eight percent of the firms in the sample report that bank corruption is a "major" obstacle. Even more substantially, the probability that firm reports bank corruption as a major obstacle decreases from $11.1 \%$ to $4.9 \%$ if a country moves from the $25^{\text {th }}$ percentile of Private Monitoring to the $75^{\text {th }}$ 
percentile. As another example, consider Chile and Canada. The Table II, column 4 regression estimates indicate that if Chile had the Supervisory Power of Canada (-2.15) instead of its own level (0.05), there would be a 2.5 -percentage point decrease in the probability that Chilean firms rank bank corruption as a major obstacle. Also, the coefficient estimates on Private Monitoring indicate that if Chile had the Private Monitoring values of Canada (1.05 instead of 0.29), there would be almost a three-percentage point drop in the probability that Chilean firms rank bank corruption as a major obstacle. Taken together if Chile adopted the supervisory power and private monitoring policies of Canada, there would be a 5.3 percentage point drop in the probability that Chilean firms report bank corruption as a major constraint on their performance and growth. ${ }^{8}$ In terms of the fit, the Pseudo R-squares range between five and nine percent, which is high for these types of crossfirm empirical studies (e.g., Beck et al., 2005)

B. Robustness to controlling for other country factors

Although the Table II results hold when controlling for an array of firm-specific and country-specific traits, there may exist concerns that the supervisory variables are proxying for other country-specific factors. Countries with different characteristics may choose different supervisory practices. At the same time, these different country-specific traits may drive the integrity of bank lending. Thus, we need to assess whether some third factor is driving both the selection of the supervisory policies and the financing obstacles reported by firms.

The robustness checks in Table III indicate that data are (i) inconsistent with the supervisory power view, (ii) consistent with the political/regulatory capture view, and (iii) supportive of the private monitoring view. Specifically, when we control for the overall level economic development by including real per capital GDP (column 1), Supervisory Power enters positively and significantly

\footnotetext{
${ }^{8}$ Note, we include these examples for illustrative purposes only. These conceptual experiments do not explain how to convince countries to change supervisory policies, and the reforms to Chilean policies contemplated in the experiments
} 
at the five percent level while Private Monitoring enters negatively and significantly at the ten percent level, which reflects the very strong, positive correlation between Private Monitoring and GDP per capita (a correlation coefficient of 0.69). Moreover, even when controlling for (1) the percentage of the banking industry owned by the government (State Ownership), (2) a dummy variable of whether the country recently experienced a systemic banking crisis (Banking Crisis), (3) the degree to which laws protect shareholder rights (Shareholder Rights), the data continue to indicate (i) a strong positive relationship between Supervisory Power and Bank Corruption and (ii) a strong, negative relationship between Private Monitoring and the degree to which corruption of bank officials hinders firm performance (Table III, columns 2-4). ${ }^{9}$

Furthermore, we were concerned that an individual firm's response to a question about the degree to which bank corruption hinders that firm's access to credit would simply reflect beliefs about the overall level of corruption in the country and not specific information about the integrity of bank-firm relationships. Thus, in column 5 of Table III, we control for the overall level of corruption in the economy by using the ICRG indicator of corruption, where higher values indicate less corruption. While (a) Corruption enters significantly and (b) the very strong correlation between Corruption and Supervisory Power (correlation coefficient of 0.60) drives out the significance of Supervisory Power, we continue to find that (1) Supervisory Power does not enter with a negative coefficient, which contradicts the supervisory power view and (2) Private Monitoring exerts a negative impact on corruption in lending.

To control for the general institutional environment, we include indicators of both legal system and government effectiveness. In particular, Rule of Law measures the quality of contract

\footnotetext{
are not marginal changes.

${ }^{9}$ We also controlled for (1) a measure of the level of legal protection of creditors from La Porta et al (1998) and (2) a measure of regulatory impediments on banking operations from the Heritage Foundation. Controlling for these country traits does not change the results.
} 
enforcement and the court system. Government Effectiveness is based on survey information on the competence and efficiency of the bureaucracy and public sector. Again, the data are inconsistent with the supervisory power view: Supervisory Power does not enter negatively in either regression 6 or 7 . As reported in Table I, however, there is a strong negative correlation between Supervisory Power and both the Rule of Law (-0.45) and Government Effectiveness (-0.47). This drives out the independent significance of Supervisory Power when these institutional variables are included in regressions 6 and 7. Nonetheless, while Supervisory Power tends to be higher in countries with low levels of the Rule of Law and low levels of Government Effectiveness, Supervisory Power does not have a positive influence on the integrity of bank lending. Thus, Supervisory Power is not beneficial; rather, it is associated with higher corruption in lending and lower levels of institutional development. Furthermore, the results support the private monitoring view. Even though Private Monitoring is highly, positively correlated with the Rule of Law (0.58) and Government Effectiveness (0.59) (Table I.C), Private Monitoring enters the bank corruption regression negatively and significantly when controlling for the Rule of Law at the 10 percent level (regression 6) and negatively and significantly at the five percent level when controlling for Government Effectiveness (regression 7). Thus, even when controlling for firm specific traits, economic growth, overall financial development, the power of the supervisory agency, and measures of institutional development, the regression results indicate that Private Monitoring lowers the degree to which firm report that corruption in lending hinders firm operations and growth. ${ }^{10}$

\footnotetext{
${ }^{10}$ We also conducted robustness tests controlling for the overall political environment. Specifically, we included an indicator of the degree to which citizens can select, monitor, and remove the executive and legislative officials (Voice and Accountability). We also controlled for (i) the degree of checks and balances in the political system by including the number of veto players in the political decision process and (ii) competitiveness of legislative elections. This paper's conclusions are robust to the inclusion of these political variables.
} 


\section{Nonlinear Effect: Interaction Terms}

Some versions of the political/regulatory capture and private monitoring views suggest a nonlinear relationship between corruption in lending and supervisory practices. Specifically, the private monitoring view holds that when supervisory agencies force banks to disclose accurate information to the public, then private investors can use this information to exert effective governance over banks with positive implications for the integrity of bank lending. This view, however, presumes that private investors have a well-functioning legal system at their disposal so that they can use this information to improve bank operations. Furthermore, this view presumes that the government is effective at forcing banks to disclose accurate information. That is, the government not only has statutes requiring banks to disclose accurate information, it successfully induces banks to disclose this information to the public. From this perspective, improvements in information disclosure rules will only improve the quality of bank lending when the legal system and government work effectively. We test this. Furthermore, the political/regulatory capture view holds that powerful supervisors may use their positions to alter the flow of bank credit for private or political reasons. International differences in legal and government institutions, however, may alter the degree to which supervisory agencies abuse their powers. That is, effective institutions may reduce the ability of supervisory agencies to promote private, rather than public, interests. From this perspective, increases in supervisory power may only hurt the quality of bank lending when institutions do not work very effectively. We examine whether the impact of both Supervisory Power and Private Monitoring on corruption in lending depends on national institutions.

In Table III (regressions 8 and 9), we include interaction terms to test for possible nonlinear relationships between supervisory policies, institutional development, and corruption in lending. More specifically, in regression 8 , we include two interaction terms: the interaction between the 
Rule of Law and Supervisory Power and Private Monitoring. In regression 9, we include two different interaction terms: the interaction between Government Effectiveness and Supervisory Power and Private Monitoring. Since these indicators are principal components indicators, we add five to Supervisory Power, Private Monitoring, Rule of Law, and Government Effectiveness in regression 8 and 9 so that none of the observations is zero or negative, which makes it possible to interpret the coefficient on the interaction term and assess the possible nonlinear impact of the supervisory indicators on corruption in lending. These regressions include each of the supervisory indicators, the institutional indicator, and two interaction terms. Since these are all highly correlated country-specific traits and there are only 37 countries in our panel of firms, it may be difficult to identify the individual effects. Nevertheless, it is valuable to assess whether supervisory practices operate differently in different settings.

We find that (1) Private Monitoring increases the integrity of bank lending in countries with sufficiently well developed legal and government institutions, but has no significant effect in countries with poor institutions and (2) Supervisory Power never has a significant, positive effect on the integrity of bank lending, even in countries with highly developed legal and government systems. More specifically, consider regression (8) in Table III, which includes the Supervisory Power, Private Monitoring, the Rule of Law and both the interaction between the Rule of Law and Supervisory Power and the Rule of Law and Private Monitoring. Note that Private Monitoring enters with a significant, positive coefficient while the interaction between Rule of Law and Private Monitoring enters with a significant negative coefficient. While the significant positive coefficient on Private Monitoring suggests that Private Monitoring increases corruption in lending, this is more than balanced by the negative coefficient on the interaction term between Private Monitoring and the Rule of Law. The derivative of regression 8 with respect to Private Monitoring equals 1.38 - 
$0.34 *($ Rule of Law). This is only positive for the three countries with the lowest values of the Rule of Law (Kenya, Guatemala, and Nigeria) and for these countries we cannot reject the null hypothesis that the effect of a marginal increase in Private Monitoring has no effect on corruption in lending. For the next 12 countries with low levels of the Rule of Law, the marginal effect of Private Monitoring is negative (i.e., it lowers corruption) but again we cannot reject the null hypothesis that the effect is statistically insignificant. For the 22 countries with the highest levels of the Rule of Law, we find that a marginal increase in Private Monitoring exerts a significant, negative impact on corruption in lending. In regression 9, which focuses on Government Effectiveness, we find the same result and similar cut-offs. Critically, a marginal increase in Private Monitoring never significantly increases corruption in lending. Rather, Private Monitoring significantly reduces corruption in lending in the 22 (out of the 37) countries in our sample with the highest levels of Government Effectiveness and the Rule of Law.

In terms of Supervisory Power, the results confirm that Supervisory Power does not increase the integrity of bank lending, even when accounting for cross-country differences in institutional development. First, note that Supervisory Power and the interaction terms between Supervisory Power and the Rule of Law never enter significantly. Second, while the individual coefficients are insignificant, it is still possible to compute whether the joint effect of a marginal increase in Supervisory Power exerts a significant impact on bank corruption at different levels of the Rule of Law and Government Effectiveness. When we do this, we never find that an increase in Supervisory Power exerts a significant negative impact on bank corruption. Thus, the results are clearly inconsistent with the supervisory power view: The marginal impact of official supervisory power on corruption in lending is either positive or insignificant. ${ }^{11}$

\footnotetext{
${ }^{11}$ In terms of the Rule of Law and Government Effectiveness, note that the direct effect of these two institutional indicators is positive in regressions 8 and 9, but one must also account for the indirect effects associated with the
} 
The results using interaction terms stress three hypotheses. First, there is no evidence that empowering official supervisors improves the integrity of bank lending. Second, for the bulk of the sample, promoting the dissemination of transparent information about banks reduces corruption in lending. Third, the positive impact of Private Monitoring on the integrity of lending depends on legal institutions and government effectiveness: Private Monitoring exerts a more positive impact on lending integrity in better functioning institutional settings.

\section{Endogeneity, the distribution of responses, and outliers}

We were concerned that since we do not have a balanced distribution of responses across the four categories of answers regarding corruption of bank lending, that this might invalidate the ordered probit estimator or that a few outliers in one of the categories with a small number of responses could exert an undue influence on the results. As mentioned, 65 percent of firms responded that corruption in bank lending is not a significant barrier to firm growth, while 35 percent indicated that bank corruption is an obstacle with some indicating it is a minor, moderate, or major obstacle. Thus, we did two robustness checks. First, we omitted each country one-at-a-time to see if firm responses from any single country drive the results. The results hold. Second, we employed a probit estimator, where we simply designate the bank corruption variable as equal to zero when firms respond that corruption is no obstacle and give the bank corruption variable a one for all other responses. This produces a comparatively balanced sample of responses for the probit estimation.

\footnotetext{
interaction terms. When doing this, two results are important from the parameters estimates in equations 8 and 9: (1) for no country in the sample does an increase in the Rule of Law or Government Effectiveness imply a significant increase in corruption in lending and (2) for 11 countries in the sample, an increase in the Rule of Law or Government Effectiveness implies an significant reduction in corruption in lending after controlling for all of the other control variables listed in Table III.
} 
As shown in regressions 1-4 of Table IV, this paper's results hold when using the probit estimator. Again, note that in regression 4, we control for individual firm responses to the question, "How problematic is financing for the operation and growth of your business?" By controlling for each firm's views on the degree to which general financial obstacles hinder firm growth, we identify the specific link between supervisory practices and corruption in bank lending and abstract from the possibility that particular firms are simply pessimistic about their financing and growth opportunities. In regression 1-4, Supervisory Power never enters negatively; rather, Supervisory Power enters with a positive and significant coefficient. These findings are inconsistent with the supervisory power view and broadly supportive of the predictions from the political/regulatory capture hypothesis. Moreover, Private Monitoring always enters negatively and significantly, which indicates that supervisory policies that force the accurate disclosure of information by banks to the public enhance lending integrity. We also find that the probit model performs relatively well, correctly predicting at least $65 \%$ of all observations.

Next, we were concerned about possible endogeneity. This is less of a concern than in pure cross-country analyses because we are examining the impact of policies on individual firms. It seems unlikely that an individual firm's views about corruption in lending will influence national bank regulatory policies. Nonetheless, there may be feedback from the corporate sector to policy or some third factor may be driving the results. Thus, regressions 5-8 of Table IV present instrumental variable probit analyses. ${ }^{12}$ We base the selection of instrumental variables on the theory and empirical work in Barth, Caprio, and Levine $(2004,2005)$, who study the determinants of international differences in bank supervisory and regulatory policies. In particular, we include the absolute value of a country's latitude, ethnic fractionalization, and the length of time it has been

\footnotetext{
${ }^{12}$ Note, instrumental variable estimators have not been developed, to our knowledge, for the ordered probit specifications used in earlier tables.
} 
independent. We include latitude because a growing body of work suggests that the geographical endowments encountered by Europeans as they colonized much of the world shaped the construction of institutions and policies that endured after countries gained their independence. ${ }^{13}$ In particular, Europeans frequently did not settle in large numbers in tropical climates, so they tended to form extractive regimes where small elites developed institutions and policies that facilitated their ability to extract natural resources or grow cash crops. These extractive regimes tended to create powerful administrative structures that protected the elite. In contrast, more temperate climates with greater numbers of European settlers tended to create more egalitarian policies. We include ethnic fractionalization because research indicates that more ethnically diverse economies tend to choose policies that allow those in power to expropriate resources from others (Easterly and Levine, 1997). Thus, ethnically diverse countries tend to choose policies associated with slower economic growth. Finally, we include the percentage of years that the country has been independent since 1776 because countries that gained their independence in the $18^{\text {th }}$ or $19^{\text {th }}$ centuries had more opportunity to modify colonial institutions and policies and adopt policies more conducive to broadbased economic growth (Easterly and Levine, 1997). These instruments explain cross-country differences in Private Monitoring and Supervisory Power, i.e., we reject the null hypothesis at the five percent level that the instruments do not explain the supervisory policy indicators. We do not claim that these instruments are the only, or necessarily the best, exogenous explanations of bank supervisory practices. Rather, we hold that the instruments are reasonably exogenous, past theoretical and empirical work suggests that these instruments will explain policies today, and the first-stage results confirm that these are worthwhile instruments.

\footnotetext{
${ }^{13}$ See Acemoglu, Johnson, and Robinson (2001), Engerman and Sokoloff (1997), Beck, Demirguc-Kunt, and Levine (2003), Easterly and Levine (2003), and the review by Levine (2005).
} 
The instrumental variable regression results suggest that (1) Supervisory Power exerts a positive - not a negative - effect on corruption in lending and (2) Private Monitoring lowers the degree to which firms respond that corruption in bank lending hinders firm operations. As shown in regressions $5-8$ of Table IV, Supervisory Power enters positively and significantly at the one percent level in all of these regressions which control for potential simultaneity bias. Furthermore, Private Monitoring enters negatively and significantly at the one percent level in all of the specifications. Thus, even when using instrumental variables and while controlling for firm specific traits and country characteristics, such as inflation, economic growth, financial development, the level of economic development, the extent of national corruption, the results are consistent with the private monitoring view, inconsistent with the supervisory power view, and generally supportive of the political/regulatory capture view of bank supervision.

\section{E. Different samples and estimation procedures}

This sub-section presents robustness checks using different sub-samples and estimators.

First, we test whether the results are robust to only including the sub-sample of firms that actually receive bank financing. The full sample might contain firms that have not applied for bank credit, either because they feel discouraged or because they do not need it. The results hold with this sub-sample (Table V, column 1).

Second, we also tested whether the results are robust to only including the sub-sample of firms that do not receive bank financing to see if they have a different perception of the importance of the corruption of bank officials in raising capital. Again, we obtain very similar results with this sub-sample. (Table V, column 2). 
Third, the number of firms varies substantially across countries. Though we use an ordered probit estimator with robust standard errors and allow for clustering within countries, we assess the robustness of the results using a weighted ordered probit. The weights are the inverse of the number of firms. ${ }^{14}$ The results are robust to this estimation procedure (Table V, column 3).

\section{Conclusion}

This paper (1) documents the relationship between bank supervision and the degree to which bank corruption is an obstacle to firms raising external finance and (2) provides evidence on different theories of bank supervision. The results support three conclusions about which bank supervisory practices work best to ease the external financing obstacles faced by firms.

First, the data are strongly inconsistent with the view that powerful supervisory agencies with the authority to directly monitor and discipline banks facilitate efficient corporate finance. The results indicate that countries with stronger supervisory agencies - countries where supervisory agencies can intervene banks, replace managers, force provisioning, stop dividends, etc. - tend to have firms that face greater obstacles to obtaining bank loans because of corrupt bank officials than firms in countries where the supervisory agency is less powerful. The results are inconsistent with theories that hold that powerful official supervisory agencies promote social welfare by overcoming information and enforcement costs and efficiently monitoring banks.

Second, the results provide some support for the political/regulatory capture view, which emphasizes that powerful supervisory agencies are prone to capture and manipulation by politicians, regulators, or both. Specifically, we find that powerful supervisory agencies tend to lower the

\footnotetext{
${ }^{14}$ Note, it is not appropriate to run a pure cross-country regression while averaging across the financing obstacle variables for each country because (i) the composition of firms varies substantially across countries and (ii) the polychotomous nature of the financing obstacles data suggest the use of an ordered probit, while controlling for individual firm traits.
} 
integrity of bank lending. This conclusion needs to be tempered, however. Powerful supervision is so strongly correlated with poor national institutions (government ineffectiveness, the absence of the rule of law, high national corruption) that it is difficult to identify an independent relationship between supervisory power and bank corruption when controlling for these institutional traits.

Third, the analyses are consistent with the private monitoring view. In particular, bank supervisory strategies that focus on forcing accurate information disclosure and not distorting the incentives of private creditors to monitor banks facilitate efficient corporate finance. These findings are consistent with approaches that simultaneously recognize that private agents face substantive information and enforcement costs when monitoring banks, while also recognizing that politicians and regulators will act in their own interests and not necessarily act to reduce market frictions. In extensions, we find that private monitoring exerts a particularly beneficial effect on the integrity of bank lending in countries with sound legal and bureaucratic institutions. These results on private monitoring support the Basel Committee's recent emphasis on the importance of private sector monitoring of banks (Basel II's third pillar).

At a very general level, these results emphasize the importance of both market and political failures. Bank supervision clearly matters. Bank supervisory policies that ameliorate market failures by forcing the accurate disclosure of information reduce the obstacles that firms face in raising external finance. This is not a laissez faire finding. This result suggests that active bank supervision can help ease information costs and improve the integrity of bank lending. Just as clearly, however, the results highlight the importance of theories that emphasize political and regulatory capture and suggest that powerful supervisory agencies too frequently do not act in the best interests of society. 


\section{References:}

Acemoglu, Daron, Simon Johnson, and James A. Robinson. 2001. “The Colonial Origins of Comparative Development: An Empirical Investigation," American Economic Review, 91, $1369-401$.

Atkinson, A.B. and J.E. Stiglitz. 1980. Lectures on Public Economics, London: McGraw-Hill.

Barth, J. R., Caprio, G. Jr., and R. Levine. 2004. "Bank Supervision and Regulation: What Works Best?" Journal of Financial Intermediation, 13, 205-48.

Barth, J.R. Caprio, G. Jr. and R. Levine. 2005. Rethinking Bank Regulation: Till Angels Govern. Cambridge: Cambridge University Press, forthcoming.

Beck, Thorsten, Asli Demirgüç-Kunt, and Ross Levine. 2003a. "Law, Endowments, and Finance." Journal of Financial Economics, 70, 137-81.

Beck, T. and R. Levine. 2005. "Legal Institutions and Financial Development." in Handbook of New Institutional Economics. Claude Menard and Mary Shirley, Eds., The Netherlands: Springer.

Beck, T., Demirguc-Kunt, A., and V. Maksimovic. 2005. "Financial and Legal Constraints to Firm Growth: Does Size Matter," Journal of Finance, forthcoming.

Becker, G. 1983. "A Theory of Competition among Pressure Groups for Political Influence," Quarterly Journal of Economics 98, 371-400.

Becker, G. 1968. “Crime and Punishment: An Economic Approach,” Journal of Political Economy $76,169-217$.

Becker, G. and G. Stigler. 1974. "Law Enforcement, Malfeasance, and the Compensation of Enforcers," Journal of Legal Studies 3, 1-18.

Boyd, J.H., Levine, R., and B.D. Smith. 2001. "The Impact of Inflation on Financial Sector Performance," Journal of Monetary Economics 47, 221-48.

Buchanan, J.M. and G. Tullock. 1962. The Calculus of Consent. University of Michigan Press.

Caprio, G. and D. Klingebiel, 1999, "Episodes of Systematic and Borderline Financial Distress”, World Bank.

Coase, R.H. 1960. “The Problem of Social Cost,” Journal of Law and Economics 3, 1-44.

Coase, R.H. 1988. The Firm, the Market, and the Law, Chicago: University of Chicago Press. 
Demirgüç-Kunt, A. and E. Detragiache. 2002. "Does Deposit Insurance Increase Banking System Stability? An Empirical Investigation.” Journal of Monetary Economics 49(7), 1373-1406.

Demirgüç-Kunt, A. and V. Maksimovic. 1998. "Law, Finance, and Firm Growth,” Journal of Finance 53, 2107-2137.

Easterly, William and Ross Levine. 1997. “Africa’s Growth Tragedy: Policies and Ethnic Divisions." Quarterly Journal of Economics, 112, 1203-1250.

Easterly, William and Ross Levine. 2003. “Tropics, Germs, and Crops.” Journal of Monetary Economics, 50, 3-39.

Engerman, Stanley L., and Kenneth L. Sokoloff. 1997. "Factor Endowments, Institutions, and Differential Paths of Growth among New World Economies," in How Latin America Fell Behind. Stephen Haber, ed. Stanford, CA: Stanford University Press, pp. 260-304.

Fazzari, S. M., R. G. Hubbard, and B. C. Petersen. 1988, Financing constraints and corporate investment, Brookings Papers on Economic Activity 19, 141-195.

Glaeser, E., Johnson, S. and A. Shleifer. 2001. "Coase versus the Coasians," Quarterly Journal of Economics 116, 853-899.

Grossman, S. and O. Hart. 1980. "Disclosure Laws and Takeover Bids," Journal of Finance 35, 323-334.

Haber, S.H., A. Razo, and N. Maurer. 2003. The Politics of Property Rights: Political Instability, Credible Commitments, and Economic Growth in Mexico (Cambridge University Press).

Hamilton, A., Lay, J. and J. Madison. 1788. Federalist Papers (In C. Rossiter, Ed., New York: New American Library, 1961).

Hay, J.R. and A. Shleifer. 1998. "Private Enforcement of Public Laws: A Theory of Legal Reform," American Economic Review Papers and Proceedings 88, 398-403.

Hellman, J., Jones, G., Kaufmann, D. and M. Schankerman. 2000, "Measuring Governance and State Capture: The Role of Bureaucrats and Firms in Shaping the Business Environment," European Bank for Reconstruction and Development, WP \#51.

Kaplan, S. N. and L. Zingales. 1997. "Do Investment-Cash Flow Sensitivities Provide Useful Measures of Financing Constraints?" Quarterly Journal of Economics 112.

Kaufmann, D., Kraay, A., and P. Zoido-Lobatón. 1999. Aggregating Governance Indicators. World Bank Research Working Paper No. 2195.

King, R. G. and R. Levine. 1993. "Finance and Growth: Schumpeter Might Be Right," Quarterly Journal of Economics, 108, 717-38. 
La Porta, R., Lopez-de-Silanes, F., and A. Shleifer. 2005. "What Works in Securities Laws?" Harvard University, Journal of Finance, forthcoming.

La Porta, R., Lopez-de-Silanes, F., Shleifer, A., and R.W. Vishny, 1998. "Law and Finance”, Journal of Political Economy 106, 1113-1155

Levine, R. 2005. "Law, Endowments, and Property Rights," Journal of Economic Perspectives, forthcoming.

Levine, R. and S. Zervos. 1998. "Stock Markets, Banks, and Economic Growth," American Economic Review 88, 537-558.

Levine, R., Loayza, N., and T. Beck. 2000. "Financial Intermediation and Growth: Causality and Causes", Journal of Monetary Economics 46, 31-77.

Morck, R., Wolfenzon, D., and B. Yeung. 2005. "Corporate Governance, Economic Entrenchment, and Growth," Journal of Economic Literature, forthcoming.

North, D. 1990. Institutions, Institutional Change, and Economic Performance. New York: Cambridge University Press.

Olson, M. 1965. The Logic of Collective Action. Cambridge, MA: Harvard University Press.

Polinsky, M. and S. Shavell. 2000. “The Economic Theory of Public Enforcement of Law,” Journal of Economic Literature 38, 45-76.

Rajan, R. and L. Zingales. 1998. "Financial Dependence and Growth," American Economic Review $88,559-587$.

Shleifer, A. and R.W. Vishny. 1997. “A Survey of Corporate Governance,” Journal of Finance 52, 737-783.

Shleifer, A. and R.W. Vishny. 1998. The Grabbing Hand: Government Pathologies and Their Cures. Cambridge, MA: Harvard University Press.

Spiller, P. and J. Ferejohn. 1992. "The Economics and Politics of Administrative Law and Procedures: An Introduction,” Journal of Law, Economics and Organization 8, 1-7.

Stigler, G. 1971. “The Theory of Economic Regulation,” Bell Journal of Economics and Management Science 2, 3-21.

Stigler, G. 1975. The Citizen and the State: Essays on Regulation, University of Chicago Press.

Wurgler, J. 2000. "Financial Markets and the Allocation of Capital," Journal of Financial Economics 58, 187-214. 
Table I

\section{Summary Statistics and Correlations}

Summary statistics are presented in Panel A and correlations in Panels B and C, respectively. Bank Corruption is the response to the question "How problematic is corruption of bank officials for the operation and growth of your business?" General Financing Obstacle is the response to the question "How problematic is financing for the operation and growth of your business?" Answers vary between 1 (no obstacle), 2 (minor obstacle), 3 (moderate obstacle), and 4 (major obstacle). Government and Foreign are dummy variables that take the value 1 if the firm has government or foreign ownership and zero if not. Exporter is a dummy variable that indicates if the firm is an exporting firm. Manufacturing and Services are industry dummies. Sales equals the logarithm of sales in US\$. Number of Competitors is the logarithm of the number of competitors the firm has. Growth is the growth rate of GDP. Inflation is the log difference of the consumer price index. Priv is claims on the private sector by deposit money banks as share of GDP. Supervisory Power is a principal components indicator of the power of supervisory agency to discipline and monitor banks. Private Monitoring is a principal components indicator of the degree to which regulations force banks to disclose accurate, transparent information to the public and whether regulations facilitate and encourage private sector monitoring of banks. GDP per Capita is in PPP adjusted dollars and averaged over 1995-99. Corruption is a survey indicator of the absence of corruption in a country. Rule of Law and Government Effectiveness are principal component indicators of survey indicators of the legal system effectiveness and bureaucratic efficiency in a country, respectively. Shareholder Rights measures the rights of minority shareholders vis-à-vis block holders and management. State Ownership indicates the share of banks owned by the government. Banking Crisis indicates whether a country suffered a banking crisis during the 1990s. Detailed definitions and the sources are in the data appendix. *,**,*** indicate significance levels of 10,5 , and 1 percent, respectively.

\section{Panel A: Summary Statistics:}

$\begin{array}{lrrrrrr} & \text { Mean } & \text { Median } & \text { St.Dev. } & \text { Maximum } & \text { Minimum } & \text { Observations } \\ \text { Bank Corruption } & 1.58 & 1.00 & 0.93 & 4.00 & 1.00 & 2,510 \\ \text { General Financing Obstacle } & 2.58 & 3.00 & 1.13 & 4.00 & 1.00 & 2,510 \\ \text { Government } & 0.06 & 0.00 & 0.24 & 1.00 & 0.00 & 2,510 \\ \text { Foreign } & 0.25 & 0.00 & 0.44 & 1.00 & 0.00 & 2,510 \\ \text { Exporter } & 0.43 & 0.00 & 0.50 & 1.00 & 0.00 & 2,510 \\ \text { Sales } & 15.16 & 16.01 & 5.12 & 25.33 & -2.12 & 2,510 \\ \text { Number of Competitors } & 0.72 & 0.69 & 0.30 & 2.20 & 0.00 & 2,510 \\ \text { Manufacturing } & 0.39 & 0.00 & 0.49 & 1.00 & 0.00 & 2,510 \\ \text { Services } & 0.46 & 0.00 & 0.50 & 1.00 & 0.00 & 2,510 \\ \text { Inflation } & 0.10 & 0.06 & 0.12 & 0.58 & 0.00 & 37 \\ \text { Growth } & 0.02 & 0.01 & 0.02 & 0.04 & -0.02 & 37 \\ \text { Priv } & 0.45 & 0.38 & 0.32 & 1.16 & 0.04 & 37 \\ \text { Supervisory Power } & -0.11 & 0.05 & 1.09 & 1.14 & -3.05 & 37 \\ \text { Private Monitoring } & 0.20 & 0.29 & 0.77 & 1.46 & -1.56 & 37 \\ \text { GDP per Capita } & 9,226 & 6,035 & 8,246 & 30,056 & 554 & 37 \\ \text { Corruption } & 3.30 & 3.00 & 1.18 & 1.32 & 6.00 & 37 \\ \text { Rule of Law } & 0.24 & 0.13 & 0.89 & -1.22 & 1.94 & 37 \\ \text { Government Effectiveness } & 0.30 & 0.04 & 0.88 & -1.32 & 2.08 & 37 \\ \text { Shareholder Rights } & 3.15 & 3 & 1.38 & 5 & 1 & 26 \\ \text { State Ownership } & 0.19 & 0.12 & 0.21 & 0.8 & 0 & 34 \\ \text { Banking Crisis } & 0.35 & 0 & 0.49 & 1 & 0 & 31\end{array}$


Panel B: Correlations between firm-level variables

\begin{tabular}{|c|c|c|c|c|c|c|c|c|}
\hline & $\begin{array}{l}\text { Bank } \\
\text { Corruption }\end{array}$ & $\begin{array}{l}\text { General } \\
\text { Financing } \\
\text { Obstacle }\end{array}$ & Government & Foreign & Exporter & Sales & $\begin{array}{l}\text { Number of } \\
\text { Competitors }\end{array}$ & Manufacturing \\
\hline General Financing Obstacle & $0.28 * * *$ & & & & & & & \\
\hline Government & -0.02 & $-0.04 *$ & 1 & & & & & \\
\hline Foreign & $-0.10 * * *$ & $-0.14 * * *$ & -0.02 & 1 & & & & \\
\hline Exporter & $-0.07 * * *$ & -0.01 & $0.04 * *$ & $0.22^{* * *}$ & 1 & & & \\
\hline Sales & $-0.16^{* *}$ & $-0.16^{* * *}$ & $-0.08 * * *$ & $0.13^{* * *}$ & 0.01 & 1 & & \\
\hline Number of Competitors & $0.10^{* * *}$ & $0.07 * * *$ & -0.00 & -0.03 & $0.04 * *$ & $-0.27 * * *$ & 1 & \\
\hline Manufacturing & -0.00 & 0.02 & 0.02 & $0.07 * * *$ & $0.31 * * *$ & $-0.10 * *$ & 0.01 & 1 \\
\hline Services & 0.01 & $-0.08 * * *$ & -0.02 & $-0.05 * * *$ & $-0.30 * * *$ & $0.16^{* * *}$ & $-0.11^{* * *}$ & $-0.74 * * *$ \\
\hline
\end{tabular}

\section{Panel C: Correlations between country-level variables}

\begin{tabular}{|c|c|c|c|c|c|c|c|c|c|c|c|c|}
\hline & $\begin{array}{l}\text { Bank } \\
\text { Corruption }\end{array}$ & Inflation & Growth & $\begin{array}{l}\text { Supervisory } \\
\text { Power }\end{array}$ & $\begin{array}{l}\text { Private } \\
\text { Monitoring }\end{array}$ & $\begin{array}{l}\text { GDP per } \\
\text { Capita }\end{array}$ & Priv & Corruption & $\begin{array}{l}\text { Shareholder } \\
\text { Rights }\end{array}$ & $\begin{array}{l}\text { State } \\
\text { Ownership }\end{array}$ & $\begin{array}{l}\text { Banking } \\
\text { Crisis }\end{array}$ & $\begin{array}{l}\text { Rule of } \\
\text { Law }\end{array}$ \\
\hline Inflation & $0.28 *$ & 1 & & & & & & & & & & \\
\hline Growth & $-0.31^{*}$ & $-0.36 * *$ & 1 & & & & & & & & & \\
\hline Supervisory Power & $0.36^{* *}$ & 0.22 & -0.25 & 1 & & & & & & & & \\
\hline Private Monitoring & $-0.36 * *$ & $-0.33 * *$ & 0.16 & -0.23 & 1 & & & & & & & \\
\hline GDP per Capita & $-0.46 * *$ & $-0.44 * * *$ & $0.31 *$ & $-0.43 * * *$ & $0.69^{* * *}$ & 1 & & & & & & \\
\hline Priv & -0.10 & $-0.54 * * *$ & 0.07 & -0.23 & $0.48^{* * *}$ & $0.66^{* * *}$ & 1 & & & & & \\
\hline Corruption & $-0.60 * * *$ & $-0.42 * *$ & $0.39^{* * *}$ & $-0.44 * * *$ & $0.46^{* * *}$ & $0.66^{* * *}$ & $0.47 * * *$ & 1 & & & & \\
\hline Shareholder Rights & $-0.47 * *$ & $-0.42 * *$ & $0.40 * *$ & -0.21 & 0.28 & 0.16 & 0.21 & $0.36^{*}$ & 1 & & & \\
\hline State Ownership & $0.35 * *$ & 0.23 & 0.11 & 0.13 & $-0.29 *$ & $-0.34 * *$ & -0.23 & $-0.41 * *$ & -0.27 & 1 & & \\
\hline Banking Crisis & $0.32 *$ & 0.30 & $-0.33 *$ & 0.06 & -0.05 & -0.16 & -0.14 & $-0.32 *$ & $-0.43 * *$ & 0.21 & 1 & \\
\hline $\begin{array}{l}\text { Rule of Law } \\
\text { Government }\end{array}$ & $-0.41 * *$ & $-0.44 * * *$ & $0.51 * * *$ & $-0.45 * * *$ & $0.58 * * *$ & $0.82 * * *$ & $0.65 * * *$ & $0.70^{* * *}$ & $0.35^{*}$ & -0.17 & -0.20 & 1 \\
\hline Effectiveness & $-0.43 * * *$ & $-0.53 * * *$ & $0.50 * * *$ & $-0.47 * * *$ & $0.59 * * *$ & $0.87 * * *$ & $0.70 * * *$ & $0.80 * * *$ & $0.38^{*}$ & $-0.36 * *$ & $-0.32 *$ & $0.92 * * *$ \\
\hline
\end{tabular}




\section{Table II \\ Supervision and Bank Corruption}

The underlying model is: Bank Corruption $=\beta_{1}$ Government $+\beta_{2}$ Foreign $+\beta_{3}$ Exporter $+\beta_{4}$ Manufacturing $+\beta_{5}$ Services $+\beta_{6}$ Sales $+\beta_{7}$ Number of Competitors $+\beta_{8}$ Inflation $+\beta_{9}$ Growth $+\beta_{10}$ Priv $++\beta_{11}$ Supervision $+\varepsilon$. Bank Corruption is the response to the question "Is the corruption of bank officials an obstacle for the operation and growth of your business?" General Financing Obstacle is the response to the question "How problematic is financing for the operation and growth of your business?" Answers vary between 1 (no obstacle), 2 (minor obstacle), 3 (moderate obstacle), and 4 (major obstacle). Government and Foreign are dummy variables that take the value 1 if the firm has government or foreign ownership and zero if not. Exporter is a dummy variable that indicates if the firm is an exporting firm. Manufacturing and Services are industry dummies. Sales is the logarithm of sales in US\$. Number of Competitors is the logarithm of the number of competitors the firm has. Growth is the growth rate of GDP. Inflation is the log difference of the consumer price index. Priv is claims on the private sector by deposit money banks as share of GDP. Supervisory Power is a principal components indicator of the power of supervisory agency to discipline and monitor banks. Private Monitoring is a principal components indicator of the degree to which regulations force banks to disclose accurate, transparent information to the public and whether regulations facilitate and encourage private sector monitoring of banks. The regressions are run with ordered probit. Detailed variable definitions and sources are given in the appendix. P-values are reported in parentheses. $*, * * * * *$ indicate significance levels of 10,5 , and 1 percent, respectively.

\begin{tabular}{|c|c|c|c|c|}
\hline & 1 & 2 & 3 & 4 \\
\hline Government & $\begin{array}{l}-0.148 \\
(0.339)\end{array}$ & $\begin{array}{l}-0.159 \\
(0.301)\end{array}$ & $\begin{array}{l}-0.150 \\
(0.329)\end{array}$ & $\begin{array}{l}-0.093 \\
(0.510)\end{array}$ \\
\hline Foreign & $\begin{array}{l}-0.178 \\
(0.001)^{* * *}\end{array}$ & $\begin{array}{l}-0.187 \\
(0.001)^{* * *}\end{array}$ & $\begin{array}{l}-0.178 \\
(0.001)^{* * *}\end{array}$ & $\begin{array}{l}-0.087 \\
(0.144)\end{array}$ \\
\hline Exporter & $\begin{array}{l}-0.088 \\
(0.180)\end{array}$ & $\begin{array}{l}-0.159 \\
(0.027)^{* *}\end{array}$ & $\begin{array}{l}-0.123 \\
(0.075)^{*}\end{array}$ & $\begin{array}{l}-0.126 \\
(0.100)^{*}\end{array}$ \\
\hline Manufacturing & $\begin{array}{l}0.093 \\
(0.256)\end{array}$ & $\begin{array}{l}0.090 \\
(0.265)\end{array}$ & $\begin{array}{l}0.042 \\
(0.602)\end{array}$ & $\begin{array}{l}0.080 \\
(0.288)\end{array}$ \\
\hline Services & $\begin{array}{l}0.088 \\
(0.321)\end{array}$ & $\begin{array}{l}0.146 \\
(0.104)\end{array}$ & $\begin{array}{l}0.098 \\
(0.269)\end{array}$ & $\begin{array}{l}0.166 \\
(0.035)^{* *}\end{array}$ \\
\hline Sales & $\begin{array}{l}-0.023 \\
(0.107)\end{array}$ & $\begin{array}{l}-0.020 \\
(0.114)\end{array}$ & $\begin{array}{l}-0.021 \\
(0.076) *\end{array}$ & $\begin{array}{l}-0.014 \\
(0.249)\end{array}$ \\
\hline Number of Competitors & $\begin{array}{l}0.183 \\
(0.284)\end{array}$ & $\begin{array}{l}0.099 \\
(0.513)\end{array}$ & $\begin{array}{l}0.097 \\
(0.503)\end{array}$ & $\begin{array}{l}0.116 \\
(0.381)\end{array}$ \\
\hline Inflation & $\begin{array}{l}1.023 \\
(0.128)\end{array}$ & $\begin{array}{l}1.477 \\
(0.046)^{* *}\end{array}$ & $\begin{array}{l}1.520 \\
(0.051)^{*}\end{array}$ & $\begin{array}{l}1.670 \\
(0.021)^{* *}\end{array}$ \\
\hline Growth & $\begin{array}{l}0.035 \\
(0.784)\end{array}$ & $\begin{array}{l}0.183 \\
(0.233)\end{array}$ & $\begin{array}{l}0.222 \\
(0.171)\end{array}$ & $\begin{array}{l}0.276 \\
(0.068)^{*}\end{array}$ \\
\hline Priv & $\begin{array}{l}-6.170 \\
(0.375)\end{array}$ & $\begin{array}{l}-7.628 \\
(0.208)\end{array}$ & $\begin{array}{l}-4.999 \\
(0.401)\end{array}$ & $\begin{array}{l}-2.896 \\
(0.613)\end{array}$ \\
\hline Supervisory Power & $\begin{array}{l}0.165 \\
(0.021)^{* *}\end{array}$ & & $\begin{array}{l}0.150 \\
(0.006)^{* * *}\end{array}$ & $\begin{array}{l}0.155 \\
(0.006)^{* * *}\end{array}$ \\
\hline Private Monitoring & & $\begin{array}{l}-0.386 \\
(0.002)^{* * *}\end{array}$ & $\begin{array}{l}-0.368 \\
(0.004)^{* * *}\end{array}$ & $\begin{array}{l}-0.347 \\
(0.004)^{* * *}\end{array}$ \\
\hline General Financing Obstacle & & & & $\begin{array}{l}0.298 \\
(0.000)^{* * *}\end{array}$ \\
\hline Observations & 2510 & 2510 & 2510 & 2510 \\
\hline Pseudo R square & 0.05 & 0.05 & 0.06 & 0.09 \\
\hline
\end{tabular}


Table III

Supervision and Bank Corruption - Controlling for Other Country Characteristics

The underlying model is Bank Corruption $=\beta_{1}$ Government $+\beta_{2}$ Foreign $+\beta_{3}$ Exporter $+\beta_{4}$ Manufacturing $+\beta_{5}$ Services $+\beta_{6}$ Sales $+\beta_{7}$ Number of Competitors $+\beta_{8}$ Inflation $+\beta_{9}$ Growth $+\beta_{10}$ Priv $+\beta_{11} X+\beta_{12}$ Supervision $+\varepsilon$. Bank Corruption is the response to the question "Is the corruption of bank officials an obstacle for the operation and growth of your business?" Answers vary between 1 (no obstacle), 2 (minor obstacle), 3 (moderate obstacle), and 4 (major obstacle). Government and Foreign are dummy variables that take the value 1 if the firm has government or foreign ownership and zero if not. Exporter is a dummy variable that indicates if the firm is an exporting firm. Manufacturing and Services are industry dummies. Sales is the logarithm of sales in US\$. Number of Competitors is the logarithm of the number of competitors the firm has. Growth is the growth rate of GDP. Inflation is the log difference of the consumer price index. Priv is claims on the private sector by deposit money banks as share of GDP. Supervisory Power is a principal components indicator of the power of supervisory agency to discipline and monitor banks. Private Monitoring is a principal components indicator of the degree to which regulations force banks to disclose accurate, transparent information to the public and whether regulations facilitate and encourage private sector monitoring of banks. $\mathrm{X}$ is one of seven variables; GDP per Capita is in PPP adjusted dollars and averaged over 1995-99. Shareholder Rights measures the rights of minority shareholders vis-à-vis block holders and management. State Ownership indicates the share of banks owned by the government. Banking Crisis indicates whether a country suffered a banking crisis during the 1990s. Corruption is a survey indicator of the absence of corruption in a country. Rule of Law and Government Effectiveness are principal component indicators of survey indicators in the respective category, measuring legal system effectiveness and bureaucratic efficiency, respectively. In columns 8 ands 9 we interact (5+Private Monitoring) and (5+Supervisory Power) with (5+Rule of Law) and (5+Government Effectiveness), respectively. The regression is run with ordered probit. Detailed variable definitions and sources are given in the appendix. P-values are reported in parentheses. *,**,*** indicate significance levels of 10,5 , and 1 percent, respectively.

Inflation

Growth

Priv

Supervisory Power

Private Monitoring

GDP per Capita

State Ownership

Banking Crisis

Shareholder Rights

Corruption

Rule of Law

Government Effectiveness

Rule of Law* Supervisory Power

Rule of Law* Private Monitoring

Government Effectiveness*

Supervisory Power

Government Effectiveness*

Private Monitoring

Observations

Pseudo R square

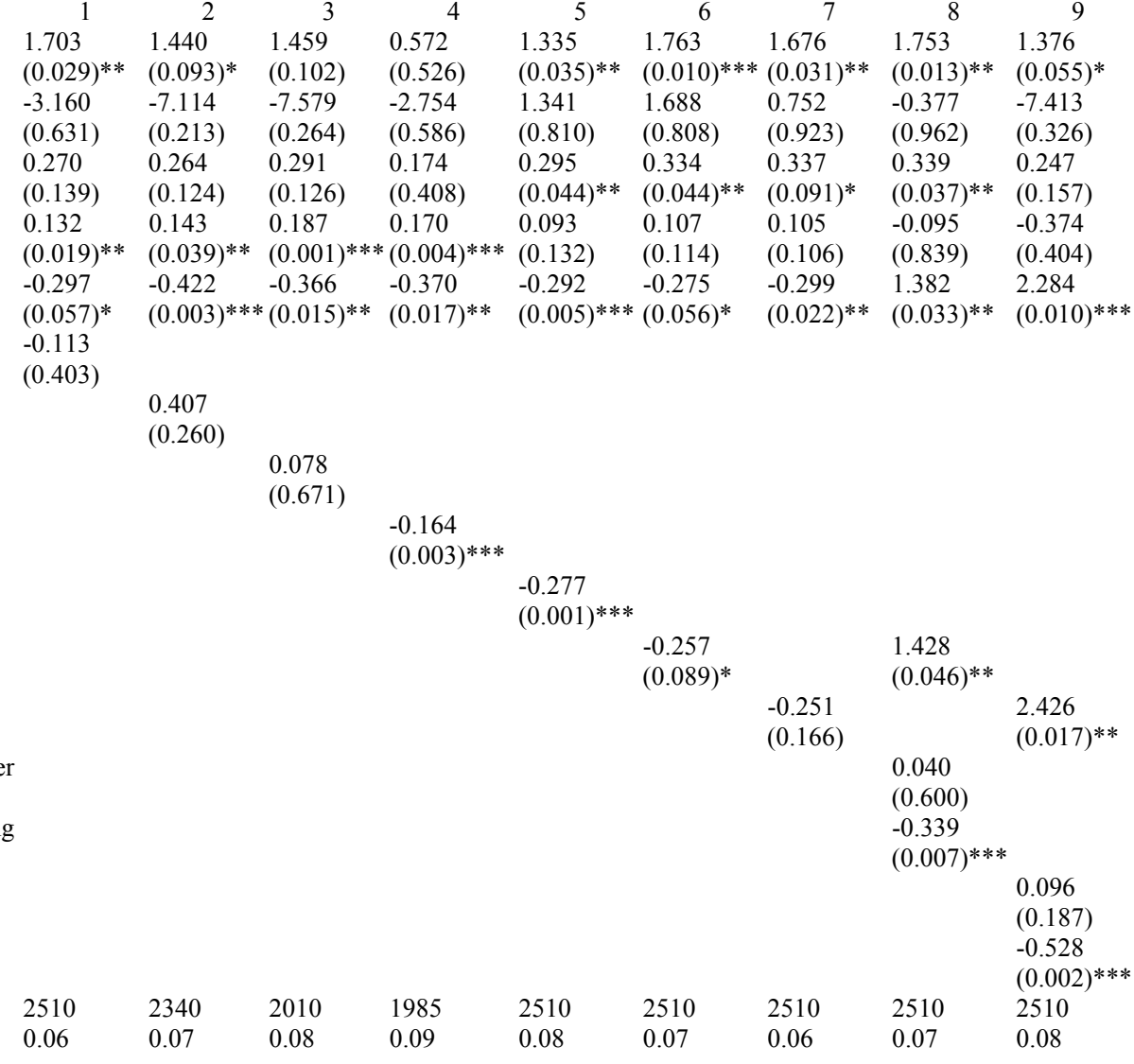




\section{Table IV \\ Supervision and Bank Corruption - Controlling for Sampling and Endogeneity Biases}

The underlying model is: Bank Corruption Dummy $=\beta_{1}$ Government $+\beta_{2}$ Foreign $+\beta_{3}$ Exporter $+\beta_{4}$ Manufacturing $+\beta_{5}$ Services $+\beta_{6}$ Sales $+\beta_{7}$ Number of Competitors $+\beta_{8}$ Inflation $+\beta_{9}$ Growth $+\beta_{10}$ Priv $+\beta_{11} X+\beta_{12}$ Supervision $+\varepsilon$. Bank Corruption Dummy is the response to the question "Is the corruption of bank officials an obstacle for the operation and growth of your business?", where "no obstacle" is equal to zero and "minor", "moderate" and "major" is equal to one. Government and Foreign are dummy variables that take the value 1 if the firm has government or foreign ownership and zero if not. Exporter is a dummy variable that indicates if the firm is an exporting firm. Manufacturing and Services are industry dummies. Sales is the logarithm of sales in US\$. Number of Competitors is the logarithm of the number of competitors the firm has. Growth is the growth rate of GDP. Inflation is the log difference of the consumer price index. Priv is claims on the private sector by deposit money banks as share of GDP. Supervisory Power is a principal components indicator of the power of supervisory agency to discipline and monitor banks. Private Monitoring is a principal components indicator of the degree to which regulations force banks to disclose accurate, transparent information to the public and whether regulations facilitate and encourage private sector monitoring of banks. GDP per Capita is in PPP adjusted dollars and averaged over 199599. Corruption is a survey indicator of absence of corruption in a country. General Financing Obstacle is the response to the question "How problematic is financing for the operation and growth of your business?" Detailed variable definitions and sources are given in the appendix. Regressions in columns (1) - (4) are run with probit with clustered errors, while regressions in columns (5) - (8) are run with IV probit, where the first stage regressions use ethnic fractionalization, percentage of years in independence since 1776 and a country's absolute value of latitude as instrumental variables. P-values are reported in parentheses. *,*,*** indicate significance levels of 10,5 , and 1 percent, respectively. \% correctly defined is the percentage of observations, for which the predicted value is greater (lower) than $65 \%$ if Bank corruption dummy is equal to one (zero).

\begin{tabular}{|c|c|c|c|c|c|c|c|c|}
\hline & $\begin{array}{c}1 \\
\text { Probit }\end{array}$ & $\begin{array}{c}2 \\
\text { Probit }\end{array}$ & $\begin{array}{c}3 \\
\text { Probit }\end{array}$ & $\begin{array}{c}4 \\
\text { Probit }\end{array}$ & $\begin{array}{c}5 \\
\text { IV Probit }\end{array}$ & $\begin{array}{c}6 \\
\text { IV Probit }\end{array}$ & $\begin{array}{c}7 \\
\text { IV Probit }\end{array}$ & $\begin{array}{c}8 \\
\text { IV Probit }\end{array}$ \\
\hline Inflation & $\begin{array}{l}1.612 \\
(0.036) * *\end{array}$ & $\begin{array}{l}1.726 \\
(0.027) * *\end{array}$ & $\begin{array}{l}1.456 \\
(0.017)^{* *}\end{array}$ & $\begin{array}{l}1.783 \\
(0.012)^{* *}\end{array}$ & $\begin{array}{l}1.919 \\
(0.000)^{* * * *}\end{array}$ & $\begin{array}{l}1.436 \\
(0.000)^{* * *}\end{array}$ & $\begin{array}{l}1.536 \\
(0.000) * * *\end{array}$ & $\begin{array}{l}2.083 \\
(0.000)^{* * *}\end{array}$ \\
\hline Growth & $\begin{array}{l}-2.588 \\
(0.689)\end{array}$ & $\begin{array}{l}-1.434 \\
(0.838)\end{array}$ & $\begin{array}{l}3.764 \\
(0.539)\end{array}$ & $\begin{array}{l}-0.213 \\
(0.974)\end{array}$ & $\begin{array}{l}0.532 \\
(0.829)\end{array}$ & $\begin{array}{l}-9.034 \\
(0.005)^{* * *}\end{array}$ & $\begin{array}{l}4.769 \\
(0.052)^{*}\end{array}$ & $\begin{array}{l}1.846 \\
(0.460)\end{array}$ \\
\hline Priv & $\begin{array}{l}0.221 \\
(0.170)\end{array}$ & $\begin{array}{l}0.251 \\
(0.167)\end{array}$ & $\begin{array}{l}0.300 \\
(0.034)^{* *}\end{array}$ & $\begin{array}{l}0.273 \\
(0.066)^{*}\end{array}$ & $\begin{array}{l}0.385 \\
(0.000) * * *\end{array}$ & $\begin{array}{l}0.270 \\
(0.000) * * *\end{array}$ & $\begin{array}{l}0.347 \\
(0.000)^{* * *}\end{array}$ & $\begin{array}{l}0.415 \\
(0.000)^{* * *}\end{array}$ \\
\hline Supervisory Power & $\begin{array}{l}0.169 \\
(0.004)^{* * * *}\end{array}$ & $\begin{array}{l}0.157 \\
(0.006) * * *\end{array}$ & $\begin{array}{l}0.111 \\
(0.096)^{*}\end{array}$ & $\begin{array}{l}0.171 \\
(0.005)^{* * *}\end{array}$ & $\begin{array}{l}0.322 \\
(0.000) * * *\end{array}$ & $\begin{array}{l}0.306 \\
(0.000)^{* * *}\end{array}$ & $\begin{array}{l}0.255 \\
(0.002)^{* * *}\end{array}$ & $\begin{array}{l}0.257 \\
(0.000)^{* * *}\end{array}$ \\
\hline Private Monitoring & $\begin{array}{l}-0.390 \\
(0.002)^{* * *}\end{array}$ & $\begin{array}{l}-0.345 \\
(0.027)^{* *}\end{array}$ & $\begin{array}{l}-0.313 \\
(0.001)^{* * *}\end{array}$ & $\begin{array}{l}-0.374 \\
(0.001)^{* * *}\end{array}$ & $\begin{array}{l}-0.596 \\
(0.000)^{* * *}\end{array}$ & $\begin{array}{l}-1.277 \\
(0.000)^{* * *}\end{array}$ & $\begin{array}{l}-0.336 \\
(0.000)^{* * *}\end{array}$ & $\begin{array}{l}-0.590 \\
(0.000)^{* * *}\end{array}$ \\
\hline GDP per Capita & & $\begin{array}{l}-0.071 \\
(0.608)\end{array}$ & & & & $\begin{array}{l}0.552 \\
(0.001) * * *\end{array}$ & & \\
\hline Corruption & & & $\begin{array}{l}-0.278 \\
(0.002)^{* * *}\end{array}$ & & & & $\begin{array}{l}-0.235 \\
(0.000)^{* * *}\end{array}$ & \\
\hline General Financing Obstacle & & & & $\begin{array}{l}0.289 \\
(0.000)^{* * *}\end{array}$ & & & & $\begin{array}{l}0.280 \\
(0.000)^{* * *}\end{array}$ \\
\hline Observations & 2510 & 2510 & 2510 & 2510 & 2510 & 2510 & 2510 & 2510 \\
\hline Pseudo R square & 0.09 & 0.09 & 0.11 & 0.13 & & & & \\
\hline$\%$ correctly predicted & 66.81 & 66.53 & 68.13 & 68.73 & 66.06 & 65.34 & 64.90 & 66.06 \\
\hline
\end{tabular}




\section{Table V \\ Supervision and Bank Corruption - Robustness Tests}

The underlying model is: Bank Corruption $=\beta_{1}$ Government $+\beta_{2}$ Foreign $+\beta_{3}$ Exporter $+\beta_{4}$ Manufacturing $+\beta_{5}$ Services $+\beta_{6}$ Sales $+\beta_{7}$ Number of Competitors $+\beta_{8}$ Inflation $+\beta_{9}$ Growth $+\beta_{10}$ Priv $++\beta_{11}$ Supervision $+\varepsilon$. Bank Corruption is the response to the question "Is the corruption of bank officials an obstacle for the operation and growth of your business?" Answers vary between 1 (no obstacle), 2 (minor obstacle), 3 (moderate obstacle), and 4 (major obstacle). Government and Foreign are dummy variables that take the value 1 if the firm has government or foreign ownership and zero if not. Exporter is a dummy variable that indicates if the firm is an exporting firm. Manufacturing and Services are industry dummies. Sales is the logarithm of sales in US\$. Number of Competitors is the logarithm of the number of competitors the firm has. Growth is the growth rate of GDP. Inflation is the log difference of the consumer price index. Priv is claims on the private sector by deposit money banks as share of GDP. Supervisory Power is a principal components indicator of the power of supervisory agency to discipline and monitor banks. Private Monitoring is a principal components indicator of the degree to which regulations force banks to disclose accurate, transparent information to the public and whether regulations facilitate and encourage private sector monitoring of banks. The regression in column 1 is for a sample of firms that received bank finance, while the regression in column 2 is for a sample that excludes firms that received bank finance. The regression in column 3 is weighted with the inverse of the number of firms in the country. Detailed variable definitions and sources are given in the appendix. P-values are reported in parentheses. $* * *, * * *$ indicate significance levels of 10,5 , and 1 percent, respectively.

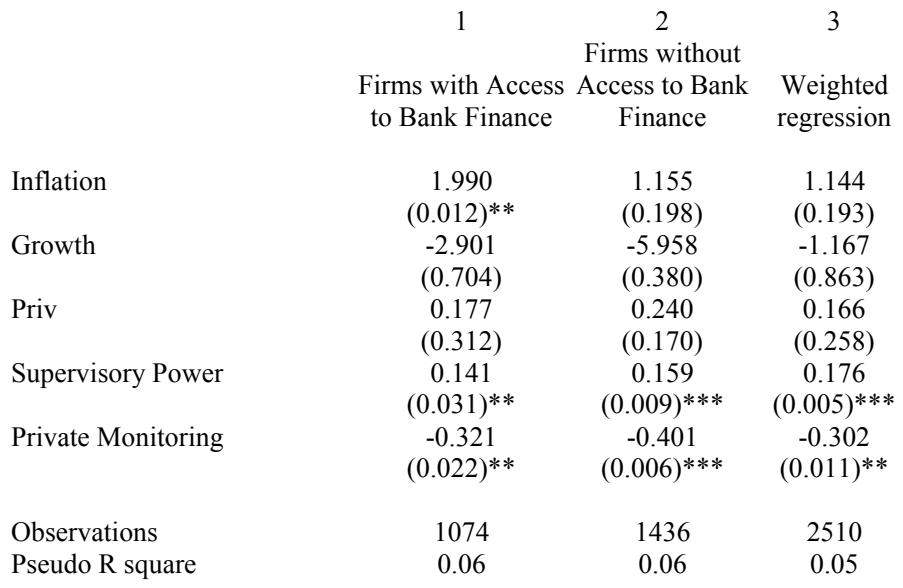




\section{Appendix Table I \\ Supervisory Practices and Country Characteristics}

Supervisory Power is a principal components indicator of the power of supervisory agency to discipline and monitor banks. Private Monitoring is a principal components indicator of the degree to which regulations force banks to disclose accurate, transparent information to the public and whether regulations facilitate and encourage private sector monitoring of banks. GDP per Capita is in PPP adjusted dollars and averaged over 1995-99. Rule of Law and Government

Effectiveness are principal component indicators of survey indicators of the legal system effectiveness and bureaucratic efficiency in a country, respectively. Detailed variable definitions and sources are given in the appendix.

\begin{tabular}{|c|c|c|c|c|c|}
\hline & $\begin{array}{r}\text { Supervisory } \\
\text { Power }\end{array}$ & $\begin{array}{r}\text { Private } \\
\text { Monitoring }\end{array}$ & $\begin{array}{r}\text { GDP per } \\
\text { Capita }\end{array}$ & Rule of Law & $\begin{array}{r}\text { Government } \\
\text { Effectiveness }\end{array}$ \\
\hline Argentina & -0.30 & 1.13 & 11,544 & 0.32 & 0.26 \\
\hline Bolivia & 0.22 & 0.06 & 2,197 & -0.35 & -0.22 \\
\hline Botswana & 0.82 & 0.97 & 6,035 & 0.5 & 0.22 \\
\hline Brazil & 1.00 & 0.97 & 6,735 & -0.22 & -0.22 \\
\hline Canada & -2.15 & 1.05 & 23,907 & 1.55 & 1.72 \\
\hline Chile & 0.05 & 0.29 & 8,188 & 1.09 & 1.17 \\
\hline Egypt & 0.38 & -0.13 & 3,035 & 0.13 & -0.14 \\
\hline El Salvador & 0.09 & 0.29 & 4,205 & -0.66 & -0.26 \\
\hline France & -1.16 & 0.69 & 22,167 & 1.08 & 1.28 \\
\hline Germany & -0.91 & 0.97 & 23,193 & 1.48 & 1.41 \\
\hline Ghana & -0.09 & -1.56 & 1,732 & -0.01 & -0.29 \\
\hline Guatemala & -0.28 & -1.14 & 3,580 & -1.11 & -0.23 \\
\hline Honduras & 0.82 & -0.42 & 2,421 & -0.9 & -0.41 \\
\hline India & -0.36 & -0.42 & 2,044 & 0.16 & -0.26 \\
\hline Indonesia & 0.74 & 0.25 & 2,912 & -0.92 & -0.53 \\
\hline Italy & -1.66 & 1.27 & 22,274 & 0.86 & 0.77 \\
\hline Kenya & 1.00 & -1.00 & 995 & -1.22 & -0.9 \\
\hline Malawi & -0.10 & -1.25 & 554 & -0.41 & -0.62 \\
\hline Malaysia & -0.25 & 0.55 & 7,743 & 0.83 & 0.71 \\
\hline Mexico & -0.17 & -0.43 & 7,589 & -0.47 & 0.18 \\
\hline Namibia & -0.54 & -0.13 & 5,726 & 0.95 & 0.04 \\
\hline Nigeria & 0.61 & 0.39 & 805 & -1.1 & -1.32 \\
\hline Panama & 1.14 & -0.13 & 5382 & -0.39 & -0.28 \\
\hline Peru & 0.09 & 0.29 & 4,425 & -0.52 & 0.17 \\
\hline Philippines & 0.95 & -0.63 & 3,612 & -0.08 & 0.13 \\
\hline Portugal & 1.00 & 0.97 & 14,559 & 1.08 & 1.15 \\
\hline Singapore & -3.05 & 0.35 & 19,456 & 1.94 & 2.08 \\
\hline South Africa & -2.95 & 0.77 & 8,902 & -0.35 & -0.01 \\
\hline Spain & -0.32 & 0.97 & 1,7052 & 1.03 & 1.6 \\
\hline Sweden & -1.55 & 0.69 & 21,220 & 1.62 & 1.57 \\
\hline Thailand & 0.72 & -0.42 & 6,096 & 0.41 & 0.01 \\
\hline Trinidad \& Tobago & -0.91 & -0.43 & 7,306 & 0.51 & 0.52 \\
\hline Turkey & -0.30 & 0.69 & 5,614 & -0.01 & -0.41 \\
\hline United Kingdom & 0.59 & 1.46 & 21,654 & 1.69 & 1.97 \\
\hline United States & 1.14 & 0.97 & 30,056 & 1.25 & 1.37 \\
\hline Venezuela & 1.14 & -0.43 & 5,690 & -0.66 & -0.85 \\
\hline Zambia & 0.51 & -0.13 & 741 & -0.4 & -0.4 \\
\hline
\end{tabular}




\section{Appendix : Variables and Sources}

\author{
Variable \\ Bank Corruption \\ Banking Crisis \\ Banking Freedom
}

Corruption

Ethnic Fractionalization

Exporter

Foreign

GDP per Capita

General Financing Obstacle

Government

Government Effectiveness

Growth

Independence

Inflation

Latitude

Manufacturing

Number of Competitors

\section{Definition}

Is the corruption of bank officials no obstacle (1), a minor obstacle (2), a moderate obstacle (3) or a major obstacle (4)?

\section{Original source}

World Business Environment Survey (WBES)

Dummy variable that takes on the value one if the country suffered a Caprio and Klingebiel (1999) systemic banking crisis during the 1990s

Indicator of openness of banking and financial system: specifically, Heritage Foundation whether the foreign banks and financial services firms are able to operate freely, how difficult it is to open domestic banks and other financial services firms, how heavily regulated the financial system is, the presence of state-owned banks, whether the government influences allocation of credit, and whether banks are free to provide customers with insurance and invest in securities (and vice-versa).

The index ranges in value from 1 (very low - banks are primitive) to 5 (very high - few restrictions). Averaged over 1995-97.

Survey indicator of the absence of corruption, with higher values ICRG indicating less corruption.

Probability that two randomly selected individuals in a country will Easterly and Levine (1997) not speak the same language.

Dummy variable that takes on the value one if firm exports, zero otherwise.

World Business Environment Survey (WBES)

Dummy variable that takes on the value one if any foreign company World Business Environment or individual has a financial stake in the ownership of the firm, zero Survey (WBES) otherwise.

GDP per capita in PPP adjusted international dollars, averaged over

World Development Indicators 1995-1999

How problematic is financing for the operation and growth of your business? no obstacle (1), a minor obstacle (2), a moderate obstacle (3) or a major obstacle (4) Dummy variable that takes on the value one if any government agency or state body has a financial stake in the ownership of the firm, zero otherwise.

World Business Environment Survey (WBES)

World Business Environment Survey (WBES)

Principal component indicator of survey indicators measuring the Kaufman, Kraay and Zoidocompetence of bureaucracy and the quality of public service delivery Lobaton (1999)

Growth rate of GDP, average 1995-99

World Development Indicators

Percentage of years since 1776 that a country has been independent Easterly and Levine (1997)

Log difference of Consumer Price Index

International Financial Statistics (IFS), line 64

Absolute value of the latitude of a country's capital, normalized

Beck, Demirguc-Kunt, and Levine between zero and one

Dummy variable that takes on the value one if firm is in the

World Business Environment manufacturing industry, zero otherwise. Survey (WBES)

Regarding your firm's major product line, how many competitors do World Business Environment you face in your market?

Survey (WBES) 
Priv

Private Monitoring

Rule of Law

Sales

Services

Shareholder Rights

State Ownership

Supervisory Power $\left\{(0.5) *\left[\mathrm{~F}(\mathrm{t}) / \mathrm{P} \_\mathrm{e}(\mathrm{t})+\mathrm{F}(\mathrm{t}-1) / \mathrm{P} \_\mathrm{e}(\mathrm{t}-1)\right]\right\} /\left[\mathrm{GDP}(\mathrm{t}) / \mathrm{P} \_\mathrm{a}(\mathrm{t})\right]$, where $\mathrm{F}$ is IFS credit by deposit money banks to the private sector (lines 22d ), GDP is line 99b, P_e is end-of period CPI (line 64) and P_a is the average CPI for the year.

Principal component indicator of nine dummy variables that measure Barth, Caprio and Levine (2004) whether (1) bank directors and officials are legally liable for the accuracy of information disclosed to the public, (2) whether banks must publish consolidated accounts, (3) whether banks must be audited by certified international auditors, (4) whether $100 \%$ of the largest 10 banks are rated by international rating agencies, (5) whether off-balance sheet items are disclosed to the public, (6) whether banks must disclose their risk management procedures to the public, (7) whether accrued, though unpaid interest/principal enter the income statement while the loan is still non-performing (8) whether subordinated debt is allowable as part of capital, and (9) whether there is no explicit deposit insurance system and no insurance was paid the last time a bank failed.

Principal component indicator of survey indicators measuring the Kaufman, Kraay and Zoidoquality of contract enforcement, the police and the courts, as well as Lobaton (1999) the likelihood of crime and violence Logarithm of firm sales

World Business Environment Survey (WBES)

Dummy variable that takes on the value one if firm is in the service industry, zero otherwise.

World Business Environment Survey (WBES)

Summary indicator of the rights of minority shareholders vis-à-vis management and block holders

La Porta, Lopez-de-Silanes, Shleifer and Vishny (1998)

Percentage of banking system's assets in banks that are $50 \%$ or more Barth, Caprio and Levine (2004) government owned

Principal component indicator of 14 dummy variables: 1 .Does the Barth, Caprio and Levine (2004) supervisory agency have the right to meet with external auditors to discuss their report without the approval of the bank? 2.Are auditors required by law to communicate directly to the supervisory agency any presumed involvement of bank directors or senior managers in elicit activities, fraud, or insider abuse? 3.Can supervisors take legal action against external auditors for negligence? 4.Can the supervisory authority force a bank to change its internal organizational structure? 5.Are off-balance sheet items disclosed to supervisors? 6. Can the supervisory agency order the bank's directors or management to constitute provisions to cover actual or potential losses? 7. Can the supervisory agency suspend the directors' decision to distribute: a) Dividends? b) Bonuses? c) Management fees? 8.Can the supervisory agency legally declare-such that this declaration supersedes the rights of bank shareholders-that a bank is insolvent? 9.Does the Banking Law give authority to the supervisory agency to intervene that is, suspend some or all ownership rights-a problem bank? 10.Regarding bank restructuring and reorganization, can the supervisory agency

or any other government agency do the following: a) Supersede shareholder rights? b) Remove and replace management? c) Remove and replace directors? 